\title{
On a First-name Basis: Englishization and Naming in Flanders
}

\author{
Eline ZENNER \\ KU Leuven/FWO Flanders \\ Department of Linguistics \\ eline.zenner@arts.kuleuven.be \\ Stefania MARZO \\ KU Leuven \\ Department of Linguistics \\ stefania.marzo@arts.kuleuven.be
}

\begin{abstract}
Following and contributing to the ongoing shift from a more structuralist, system-oriented to a more pragmatic, socio-culturally oriented anglicism research, this paper verifies to what extent the global spread of English affects naming patterns in Flanders. To this end, a diachronic database of first names is constructed, which contains the top 75 most popular boy and girl names from 2005 until 2014. In a first step, the etymological background of these names is documented and the evolution in popularity of the English names in the database is charted. Results reveal no notable surge in the preference for English names. This paper complements these database-driven results with an experimental study, aiming to show how associations through referents are in this case more telling than associations through phonological form (here based on etymology). Focusing on the socio-cultural background of first names in general and of Anglo-American pop culture in particular, this second part of the study reports on results from a survey where participants are asked to name the first three (famous) people that leap to mind when hearing a certain first name (e.g. Lana, triggering the response Del Rey). Very clear associations are found between certain first names and specific celebrities from Anglo-American pop culture. Linking back to marketing research and the social turn in onomastics, we will discuss how these celebrities might function as referees, and how social stereotypes surrounding these referees are metonymically attached to their first names. Similar to the country-of-origin-effect in marketing, these metonymical links could very well be the reason why parents select specific "celebrity names". Although further attitudinal research is needed, this paper supports the importance of including sociocultural parameters when conducting onomastic research.
\end{abstract}

Keywords: socio-onomastics, globalization ,metonymy, first names, English

\section{ENGLISHIZATION AND SYMBOLIC ASSOCIATIONS}

This paper aims to add to the ongoing shift from a more structuralist, system-oriented to a more pragmatic, socio-culturally oriented anglicism research by studying the 
impact of Englishization and globalization on naming practices in Flanders. Section 2 presents the English-Dutch contact situation in Flanders. In Section 3, we provide an overview of the database and selection procedure. The selected names will be subject to an etymological analysis (Section 4) and a socio-cultural analysis (Section 5). The results of our study will be discussed and summarized in Section 6, where we also introduce some perspectives for future research. First, the remainder of this section will frame our study against the background of anglicism research in Western Europe.

\subsection{ANGLICISM RESEARCH: FROM STRUCTURALISM TO PRAGMATICS}

Being one of the most visible forms of contact-induced variation and change, lexical borrowing has received ample attention in historic and variational linguistics since the early 20th century (see Hoffer 1996). The incorporation of form-meaning pairs from a given source language into a given receptor language has been studied for many different contact settings. As a result of the worldwide spread of English (see research on World Englishes, Learner Englishes and English as a lingua franca; e.g. Wolf and Polzenhagen 2009, Mauranen and Ranta 2009, Gilquin 2015), the borrowability and adaptation of English loanwords specifically has received a prominent position in lexical borrowing research, predominantly in Western Europe.

Studies on the topic have long been conducted from a structuralist, systemoriented perspective, identifying types of anglicisms according to their degree of morpho-phonological nativization, charting borrowability of parts of speech and providing lexicographical inventories for loanwords found in print media corpora (e.g. Posthumus 1986, Yang 1996, Görlach 2001; but see Poplack et al. 1988 for an early exception). Recently, new perspectives have been introduced from various angles, studying the pragmatic and social value of English loanwords in society and discourse. The overarching question is why language users choose what type of foreign material in which contexts to achieve which social or pragmatic effect. Studies along these lines look into sociolinguistic variation in the choice for loanwords over receptor language alternatives (Onysko and Winter-Froemel 2011, Zenner et al. 2012), open up the discussion towards pragmatic, discursive and gestural borrowing (Andersen 2014, Peterson and Vaattovaara 2014) and describe receptor language users' creativity in molding and altering source language material (amongst others in the form of bilingual punning, pseudo borrowing and constructional change; see Stefanowitsch 2002, Furiassi and Gottlieb 2015 and Van de Velde and Zenner 2009, respectively). 


\subsection{SYMBOLIC ASSOCIATIONS WITH ENGLISH IN ADVERTISING AND BRAND NAMING}

In large part, this new trend has been instigated in applied linguistic research on the use of English in advertising. The studies of Piller (2001), Martin (2006), KellyHolmes (2005) and those of the Nijmegen group (see amongst others Gerritsen et al. 2007, Hornikx et al. 2007, van Meurs et al. 2013, Hendriks 2015, Hornikx and van Meurs 2015) for instance emphasize the importance of the symbolic value of the English language and English loanwords in advertising. These studies draw on what sociolinguistic research on advertising calls Foreign Language Display (see KellyHolmes 2000, 2005) and what is known in marketing research as the Country-ofOrigin effect (hence COO; see Samiee 1994; Usunier and Cestre 2007). When using a specific foreign language in advertising, speakers will associate this foreign language with features and stereotypes of the country in which the language is spoken and of its speakers. These features will then rub off on the product advertised. For example, when using Italian in an ad for olive oil, receivers of the ad will link the Italian words to Italy and Italians through the COO-effect, evoking stereotypes such as family-life ('la mama'), good food and sunshine. These evoked stereotypes will then rub off on the advertised product (provided that the product is typical for the country/countries in which the foreign language is spoken), as such creating a link in the recipient's mind between olive oil and Italian traditions (see Hornikx et al. 2013 for a wellfocused overview). English words and phrases do not per se evoke such cultural stereotypes of Great Britain and the United States: given its role as a global language, speakers instead primarily associate English with symbolic values such as internationalism, modernity, fun and trendiness (Piller 2001). This process of symbolic associations is also studied for brand and company naming: when choosing a name for a new firm, a symbolic link to successful international firms and globalized economy can be made by including English elements (Friedrich 2002, and see Chao et al. 2005; see also Leclerc et al. 1994, Lee and Baack 2014 for research on foreign languages and brand naming).

\subsection{PHONOLOGICAL AND REFERENTIAL ASSOCIATIONS IN FIRST-NAME- GIVING}

This exploitation of connotations for name-giving is not restricted to brand naming: it can also be found at the level of personal names, a so far relatively understudied field in research on Englishization (but see initial explorations in Gottlieb 2015 and Koß 2002: 116-145). In choosing a name for their child, parents reveal some kind of cultural identification with the language and culture in which that name originated (Hanks et al. 2006: xi). First names are badges of cultural identity (Finch 2008), which they acquire through two types of associative meaning. Firstly, names have 
associative meaning through their phonological shape. On a very concrete level, Daisy triggers associations with the common noun daisy 'bellis perennis' (flower). On a more abstract level, English-origin names trigger associations with Englishization and globalization through their English form (e.g. names ending in $-y$ such as Kelly or Kimberley). These phonological associations lie at the basis of the COO-effect described in marketing research. Secondly, first names acquire associative meaning through the referents that carry that specific proper name: Napoleon can trigger properties such as 'loser (of Waterloo)' (Van Langendonck 2002: 22, 82-83). Without digging deeper into the complex field of the semantics and ontology of proper names it is clear that both types of associative meaning should be taken into account when studying naming patterns.

The aim of our study is to add to the ongoing focus on the socio-pragmatics of the spread of English in Western Europe by looking into the Englishization of first names in Flanders. First names can be considered a crucial component of this sociopragmatic turn: "Of all word classes, personal names possess the greatest possibilities to take on pragma - and sociolinguistic information" (Van Langendonck 2002: 309) (see further below). A diachronic database is constructed containing the top 75 most popular boy and girl names in Flanders from the period of 2005 until 2014. The data is analyzed from two different angles, aiming to pattern both phonological and referential associations in name-giving. In the phonological realm, we study the etymological background of names and track the evolution of English names in the database. Concerning referential associations, we present the results of an association experiment meant to reveal the link between certain proper names and specific celebrities from Anglo-American pop culture. Through this combination of perspectives, our study not only relates to the new perspectives on anglicism research described above, we also contribute to the social turn in onomastics (cf. De Stefani 2016, and see below). In the next section, we first provide the necessary contextual framework for this study by briefly sketching the English-Dutch contact situation.

\section{ENGLISH-DUTCH CONTACT}

With its two national varieties, Dutch can be considered to be a pluricentric language (Clyne 1992): it is the official language of Flanders (the Northern part of Belgium) and of the Netherlands. This study focuses on Belgian Dutch speakers. Similar to Germans (Onysko 2007) or Danes (Sandoy 2013, Gottlieb 2005), most Belgian Dutch speakers are at least weakly bilingual. Although Eurobarometer data of 2012 suggests that 'only' 38 percent of Belgians claim to be able to hold a basic conversation in English, it is important to see that respondents to this survey are sampled across the three linguistic communities of Belgium (French-speaking in the South, Dutchspeaking in the North, and a German-speaking minority in the East). As such, these data are not necessarily very representative for Belgian Dutch speakers. 
In contrast to the situation for the French-speaking South of Belgium, English television programs in Flanders are subtitled instead of dubbed (Booij 2001). Factoring in the use of English on the Internet and the spread of English through pop music on the radio, there is a near-constant influx of the English language through mass media. Additionally, quite some domain loss can be noted for Flanders, with English gaining ground as the lingua franca in amongst others business contexts and academia.

This increasing use of English as a means of communication also has its effects on Dutch. Given how bilingual communication between Dutch and native English speakers is still quite rare, the impact of English is however still largely restricted to the Dutch lexicon, which is enriched with English loanwords such as manager or cool and loan phrases such as as good as it gets or what the hell (cf. Zenner et al. 2012, Zenner et al. 2013a, for other European languages, see Furiassi, Pulcini and Rodriguez-González 2012). In this paper, we aim to study another possible outcome of English-Dutch contact, namely Englishization and globalization in Flemish naming practices. To this end, a diachronic database of first names is constructed, which is presented in the next section.

\section{PERSONAL NAMES: A FLEMISH DATABASE}

Naming in general and personal names in particular have been studied in a variety of disciplines, ranging from anthropology (e.g. vom Bruck and Bodenhorn 2006) and sociology (e.g. Finch 2008) over philosophy (e.g. Frege 1892, Kripke 1980) and history (Schürer 2004) to linguistics (e.g. Anderson 2003) (see Hough 2016 for an overview, and TOC's of journals such as Names and Onoma). Linguistic perspectives often discuss typologies of proper names based on their etymological and/or semantic origin (e.g. Van Langendonck 2002). As far as person-naming is concerned, surnames have received more detailed attention than first names (see e.g. Beech et al. 2002). First names have typically been dealt with in popularizing accounts and lexicographical overviews for new parents (e.g. Tyberg 2014), or are developed with attention for "fashion trends" in naming (e.g. Koß 2002, and also popularizing accounts such as the final chapter in Levitt and Dubner 2005).

The recent social turn in onomastics has introduced new perspectives into linguistic research on personal names, with a strong focus on (critical) discourse analysis (e.g. Clifton 2013, Palsson 2014) and ethnographic analysis of data, with a strong interactional sociolinguistic focus (e.g. De Stefani and Pepin 2006, PinaCabral 2010) (see De Stefani 2016 for an overview). Additionally, experimental studies aim to measure attitudes towards different personal names, again typically adopting a socially critical perspective (e.g. Duguet et al. 2010 on discrimination in job application procedures based on first and second names). 
Our study aims to complement existing research from the field of socioonomastics by verifying whether the global spread of English has an impact on naming preferences in Flanders. A database of the top 75 boy and girl names from 2005 until 2014 is constructed and analyzed from two different perspectives. Focusing on the etymological origin of the names, we firstly verify whether a diachronic rise in the amount of English-origin names can be attested. Additionally, we track the evolution of individual English names in the database. In a second step, we are interested in the effect of referential associations on first-name-giving (i.e. based on bearers of a given name). More specifically, we will verify which celebrities leap to the minds of young Flemish men and women when hearing certain first names. For both perspectives, we rely on the online first name database of Kind and Gezin (a Flemish child welfare agency). This database is described in more detail in the next section.

\section{1. $K \& G^{\prime} S$ NAMING DATABASE}

In Belgium's federal system, child welfare was organized nationally until the state reform of 1980, when it became a regional matter. For the Flemish Community, the Nationaal Werk voor Kinderwelzijn ('National work for child welfare') was replaced by Kind en Gezin ('Child and family', henceforth K\&G). Generally, K\&G's tasks include taking to heart the wellbeing and health of Flemish children, supporting primary caretakers in looking after their child and working together with relevant official partners in this field. One important line of services in this respect concerns preventive family support, which includes sessions concerning pregnancy and childbirth, a hearing test at birth, ten general consults in the first two years of a child's life and a telephone hotline for Q\&A's.

Additionally, K\&G offers a first-name database to inspire parents who are looking for a name for their future child. This database can be consulted online, free of charge ${ }^{1}$. It contains all first names of the babies monitored by K\&G of the past ten years, with the relative (rank) and absolute (token count) popularity of the name per gender. The information can optionally be split out per province (West-Flanders, East-Flanders, Antwerp, Flemish-Brabant and Limburg).

Despite the benefit of free online consultation, the database also has some drawbacks. Firstly, parents have no obligation to visit the $\mathrm{K} \& \mathrm{G}$ consultants. Although the services are well-known and widely relied on, we have no guarantee of full representability of the Flemish community. Furthermore, the database does not offer much sociological depth, as we have no background information on the mother

\footnotetext{
${ }^{1} \mathrm{http}: / / \mathrm{www}$. kindengezin.be/toepassingen/populaire-voornamen.jsp.
} 
and father. Finally, the diachronic span is not very large, which makes it hard to pick up on slow-changing tendencies.

\subsection{DATA COLLECTION: SELECTION CRITERIA}

The present analysis focuses on the top 75 most popular boy names and girl names per year, for the period of 2005 until 2014. This restricts the analysis to highly frequent names, which are chosen approximately 100 to 500 times per year on an average of about 70.000 annual births (FOD Economie 2014). With 75 boy names and 75 girl names for a ten-year period, the database contains 1500 ranked names. For each of these names, the specific rank in the top 75 of that year was registered. The amount of occurrences for the names has not been included in our database, as this type of information only becomes relevant when considered relative to the amount of births in Flanders for each of these years. As we do not have access to this information, we have restricted the analysis to the ranks of the names.

Across the 1500 ranked names, we have 114 different boy names and 127 different girl names. Of the 114 boy names, 43 are found in the top 75 in each of the ten years under scrutiny (e.g. Daan, Arthur, Emiel), 12 occur in only one year (e.g. Eden, Amir, Jesse). Of the 127 girl names, 39 are found in each year (Louise, Emma, Amélie), 18 in only one (e.g. Aline, Maud, Stien). Below, we will have a closer look at the etymological background of the ranked names as a means to verify the impact of possible phonological associations with the English language. Selecting an English-origin name for a child might be a way to provide symbolic associations with globalization and modernity. This is similar to the COO-effect in marketing: Jamie sounds English, and hence triggers symbolic links with global English in recipients' minds. After raising some issues with this etymology-based approach, we report the results of a small experimental survey meant to measure socio-cultural associations through specific bearers of first names.

\section{ETYMOLOGICAL PERSPECTIVE}

\subsection{PROVIDING ETYMOLOGICAL EVIDENCE: MEERTENS INSTITUUT}

K\&G does not provide any semantic or etymological information for the first names listed in their database. A precise and practical alternative is offered by an online database of first names in the Netherlands, the Nederlandse Voornamen Databank of the Meertens Instituut. The Meertens Instituut, whose origin dates back to 1930, is a research institute of the Koninklijke Nederlandse Akademie van Wetenschappen ('royal Dutch academy of science') that documents the Dutch language and rituals, 
with a focus on everyday culture. Amongst others, Meertens Institute has built a large number of collections of language and culture, including the first name database. This database contains 600.000 names, and additionally provides diachronic information, semantic explanations and etymological background for about 20.000 names. The etymological analyses are based on the work of Dr. van der Schaar (further edited by Dr. Doreen Gerritzen). In turn, his work partly falls back on Graaf's 1915 Nederlandse doopnamen naar oorsprong en gebruik and on the List fan Fryske foarnammen of the Fryske Akademy.

Needless to say, follow-up research should include the evolution in name giving for Dutch parents to arrive at a comparison of naming patterns in Flanders and the Netherlands. For now, however, we restrict our attention to the Flemish data but rely on the database from Meertens Instituut to provide an etymological classification of our first names. When the database provides several possible etymological backgrounds, we follow Meertens, which typically favors one of the etymological analyses. In case of too much uncertainty, the label 'other' was assigned to the name. A case in point is the name Nina, which has French, Swedish, Italian or Russian roots. For rare cases where Meertens does not provide an etymological analysis, we combined several other online resources (such as www.babybytes.nl or www.babyflock.nl). Again, the label 'other' was assigned when no reliable etymology could be established.

\subsection{RESULTS}

Table 1 and Table 2 present the main results from the etymological analysis for the 114 boy names and 127 girl names respectively. The names are summarized by etymological origin. Additionally, the relative proportion for each origin is provided (e.g. 15\% of the individual boy names in our dataset are of Hebrew origin). Also, we provide the mean number of years the names from a certain origin are part of the top 75 , complemented with the minimum, maximum and mean rank of the different names. This provides us with a general idea of the amount of 'fashion fads'.

For both girl and boy names we immediately notice a strong impact of the classical languages Greek and Latin and of Christianity (through Hebrew names) (e.g. the very popular names Noah, Leon and Lucas) (see Koß 2002: 121 for similar results). English is not a prime resource for naming. The same result appears when we look at the amount of times the English names occur in the top 75 of the different years. The 17 English names together account for 76 out of 1500 ranked names (5\%). 
Table 1. 114 individual boy names by origin

\begin{tabular}{|c|c|c|c|c|c|c|}
\hline $\begin{array}{l}\text { origin boy } \\
\text { names }\end{array}$ & nrOfNames & percTotal & meanYearsRanked & minRank & maxRank & meanRank \\
\hline Greek & 20 & 0.18 & 7.20 & 1 & 75 & 45.38 \\
\hline Hebrew & 17 & 0.15 & 7.06 & 1 & 75 & 42.51 \\
\hline Latin & 17 & 0.15 & 6.18 & 1 & 75 & 49.57 \\
\hline Germanic & 14 & 0.12 & 5.86 & 2 & 75 & 48.11 \\
\hline English & 8 & 0.07 & 5.25 & 2 & 75 & 47.10 \\
\hline Frisian & 8 & 0.07 & 6.38 & 4 & 75 & 45.02 \\
\hline French & 6 & 0.05 & 6.83 & 1 & 75 & 49.72 \\
\hline Arabic & 4 & 0.04 & 5.25 & 32 & 73 & 54.73 \\
\hline Other & 4 & 0.04 & 3.00 & 26 & 72 & 60.65 \\
\hline Scandinavian & 4 & 0.04 & 8.00 & 6 & 75 & 44.42 \\
\hline Celtic & 3 & 0.03 & 9.33 & 3 & 73 & 36.63 \\
\hline Persian & 2 & 0.02 & 8.00 & 10 & 69 & 37.60 \\
\hline Aramaic & 1 & 0.01 & 10.00 & 4 & 30 & 15.50 \\
\hline Basque & 1 & 0.01 & 10.00 & 24 & 61 & 35.90 \\
\hline Finnish & 1 & 0.01 & 7.00 & 25 & 69 & 45.40 \\
\hline Hawaian & 1 & 0.01 & 2.00 & 30 & 46 & 38.00 \\
\hline Irish & 1 & 0.01 & 7.00 & 6 & 68 & 32.60 \\
\hline Italian & 1 & 0.01 & 10.00 & 18 & 44 & 33.90 \\
\hline Slavic & 1 & 0.01 & 10.00 & 1 & 20 & 7.60 \\
\hline
\end{tabular}

\begin{tabular}{|l|l|l|l|l|l|l|}
\hline $\begin{array}{l}\text { origin girl } \\
\text { names }\end{array}$ & nrOfNames & percTotal & meanYearsRanked & minRank & maxRank & meanRank \\
\hline Greek & 20 & 0.16 & 6.00 & 7 & 75 & 46.74 \\
\hline Hebrew & 20 & 0.16 & 6.75 & 2 & 75 & 45.94 \\
\hline Latin & 20 & 0.16 & 4.60 & 2 & 75 & 54.28 \\
\hline French & 15 & 0.12 & 8.33 & 1 & 72 & 36.56 \\
\hline Germanic & 11 & 0.09 & 6.00 & 1 & 72 & 41.30 \\
\hline Arabic & 9 & 0.07 & 6.22 & 2 & 75 & 39.39 \\
\hline English & $\mathbf{9}$ & $\mathbf{2} \mathbf{0 . 0 7}$ & $\mathbf{3 . 7 8}$ & $\mathbf{2 5}$ & $\mathbf{7 5}$ & $\mathbf{6 1 . 1 8}$ \\
\hline
\end{tabular}




\begin{tabular}{|c|c|c|c|c|c|c|}
\hline Frisian & 7 & 0.06 & 3.86 & 10 & 75 & 50.79 \\
\hline other & 4 & 0.03 & 6.75 & 9 & 70 & 47.18 \\
\hline Slavic & 3 & 0.02 & 6.00 & 10 & 74 & 46.83 \\
\hline Irish & 2 & 0.02 & 4.50 & 16 & 65 & 40.70 \\
\hline Scandinavian & 2 & 0.02 & 2.50 & 31 & 70 & 57.75 \\
\hline Aramaic & 1 & 0.01 & 7.00 & 48 & 70 & 58.30 \\
\hline Basque & 1 & 0.01 & 6.00 & 25 & 62 & 36.70 \\
\hline Italian & 1 & 0.01 & 5.00 & 25 & 69 & 43.40 \\
\hline Russian & 1 & 0.01 & 10.00 & 21 & 60 & 43.40 \\
\hline Spanish & 1 & 0.01 & 8.00 & 39 & 65 & 54.50 \\
\hline
\end{tabular}

Table 2. 127 individual girl names by origin

Figure 1 focuses on the diachronic evolution of English names in the top 75 for boys and girls in our 2005-2014 timespan. Specifically, it shows the proportion of English names in the 150 ranked names for each specific year. The plot reveals a minor rise in the popularity of English names from 2005 to 2014, though the strong Englishization one might expect based on diachronic corpus studies (Zenner et al. 2013b) is clearly absent. No significant effect for time was found ( $p$ for Chi-square $>0.1$ ). This is further confirmed by the absolute numbers (marked in red on the plot), which remain low.

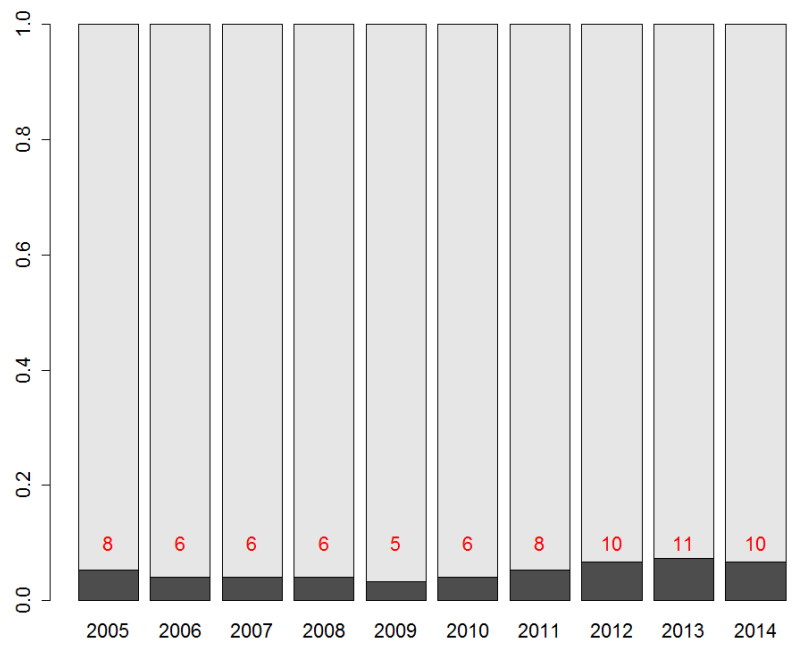

Figure 1: diachronic evolution in English names, on a total of 150 ranked names per year (boys + girls) 
As Figure 1 is based on only 17 different English names, it is possible that strong differences in the ranking evolution of the individual names distort the annual averages. Figure 2 and Figure 3 track this individual evolution more closely for boys and girls respectively, verifying whether specific English names have a surge in popularity. The $y$-axis portrays the rank of the name (rank 1 indicating the most popular name of a given year), the $\mathrm{x}$-axis lists the ten years represented in our database.

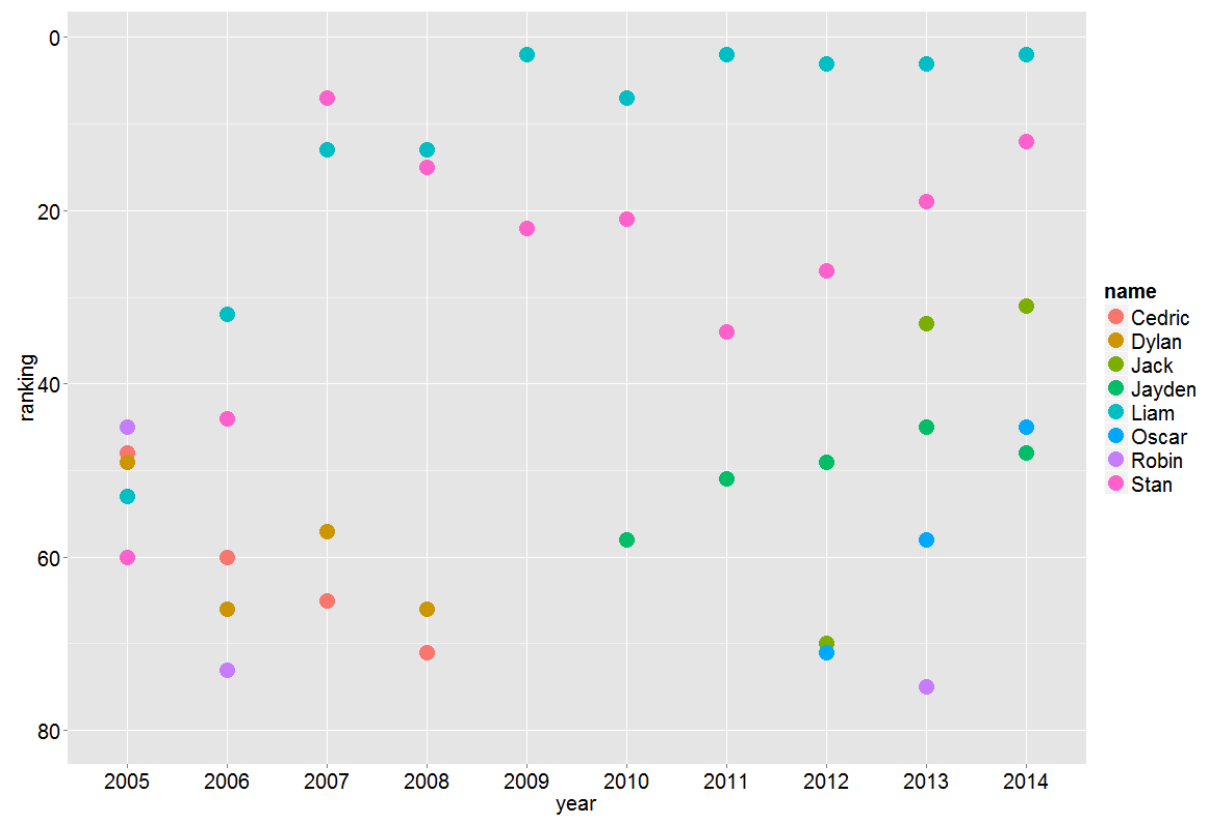

Figure 2: Diachronic evolution of the eight English boy names 


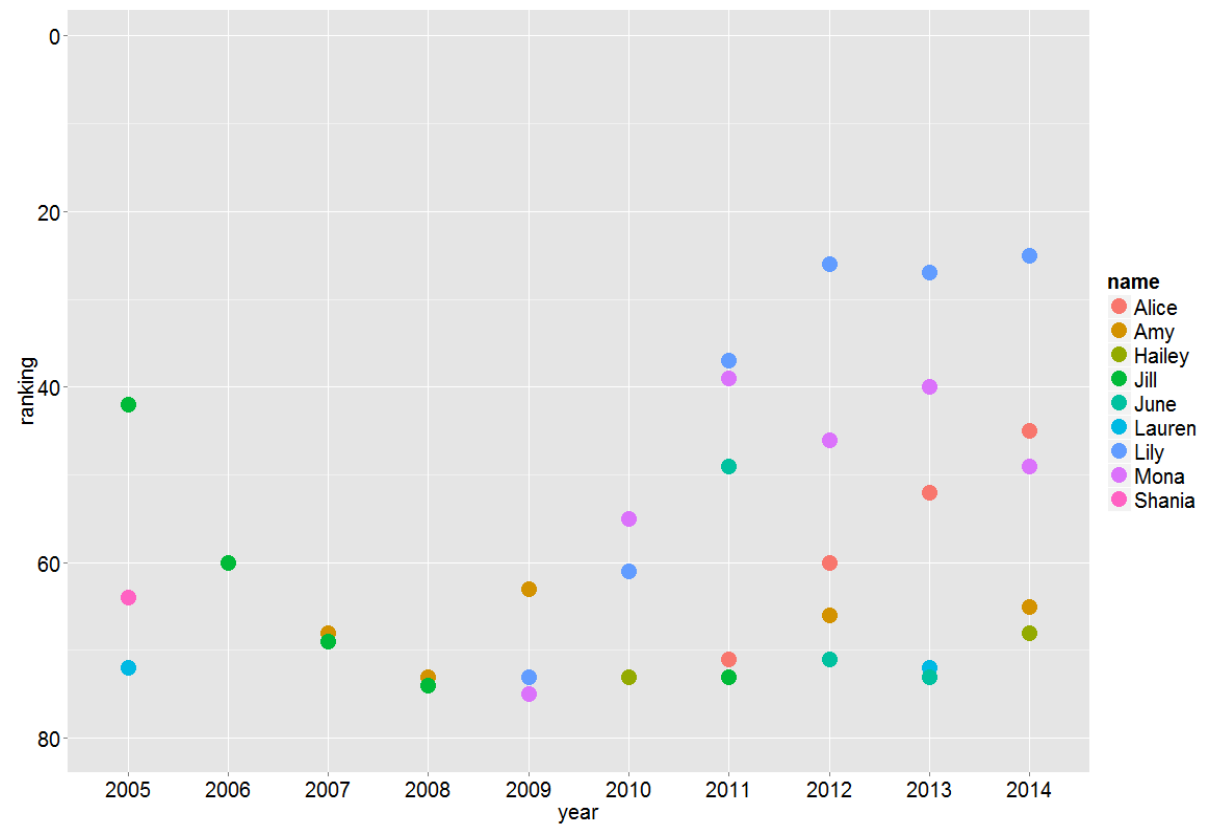

Figure 3: Diachronic evolution of the nine English girl names

A scattered and heterogeneous mix of diachronic patterns appears. A steady rise is found for names such as Alice, whereas names such as Jill and Cedric portray a clear decline. For names such as Liam and Lily, we see a clear rise followed by a period of stabilization. More complex patterns appear for Dylan and Stan, which initially show a clear rise, followed by a decline in popularity, after which the name picks up in rank again. Furthermore, we see that certain names only occur in the early years of our selection (Jill, Cedric), others creep up at the end (Alice, Jayden) and still others occur throughout (Amy, Stan). Note that this does not necessarily entail that these names do not appear at all in Flanders: it only means that they were not selected frequently enough to make it to the top 75 .

Overall, we do not find proof of first-name-curves in our database (see Lukas 1981, described in Koß 2002). Given the rather whimsical behavior of the data, it is not certain that expanding the diachronic reach of our database would reveal such curves either. Furthermore, our data provide no support for a growing popularity of English names in the past ten years, despite the strong position of English in Flanders (see Zenner et al. 2013b for a diachronic analysis of English in Dutch job ad magazines). In conclusion, associating children with internationalism and modernity through the selection of English-origin names does not seem to present a notable trend in our Flemish database.

Tracing the etymological origin of English names might however not be the best way to monitor parents' symbolic associations with a given first name. Firstly, 
etymology does not necessarily provide the best information to measure phonological associations through English sounds. Most importantly, not all names that have etymologically English roots are felt to be English. A case in point is Cedric, a name that typically has a French pronunciation in Flanders. A possible solution could be to introduce Onysko's criterion of foreignness, also used in Zenner et al. (2012). Following this criterion, the analysis would only consider as English those first names that are structurally recognizable as English to a naïve native speaker "due to the fact that they largely retain their English graphemic-phonemic correspondence" (Onysko 2007: 10). By means of an example, compare the common nouns film and manager. Both are English loans, but whereas a naïve Dutch pronunciation of the written form film sounds very close to English, a naïve Dutch pronunciation of manager would sound more like /ma'na: $\gamma ə r /$. Hence, it is reasonable to assume that Belgian Dutch speakers would recognize manager, but not film, as English-origin word. This criterion is however not very applicable to proper names, as they are typically prone to variation in pronunciation. For example, Sam can in Flanders be pronounced as $/ \mathrm{sam} /$ (a Dutch pronunciation), but also as $/ \mathrm{scm} /$ (an English pronunciation). Phonological associations with English and global stereotypes are far more likely in the latter case than in the former.

A second issue with etymological data concerns the neglect of referential associations. Proper names not only acquire associative meaning through their form, but also through their referents, i.e. through the people bearing the name. As a consequence, names that are etymologically not English can still be linked to English, Anglo-American pop culture and globalization through the referents of the name. The Slavic name Lana can, for example, trigger symbolic associations with globalization and modernity through its famous bearer Lana del Rey. This type of referential association is not accounted for in the etymological analyses presented above.

In sum, an analysis of etymological origins of first names might not be the best way to measure (phonological) associations with proper names. As an alternative, we will present an explorative study on the strength of referential associations through bearers of a name below.

\section{SOCIO-CULTURAL PERSPECTIVE}

As Van Langendonck (2002) describes, names can trigger symbolic associations through the bearers of that name. As he describes, most people will immediately link the name Napoleon to that one specific referent of the name, 'the loser of Waterloo'. Through metonymical links, the strong symbolic associations between a name and the properties of its bearers can become stereotypes, evoked whenever one hears that name (compare Kristiansen 2008 on accents, metonymies and stereotypes). In this vein, first names that are linked to bearers known from Anglo-American pop culture can come to evoke characteristics of Anglo-American pop culture and, by extension, 
of globalization and modernity. When parents select a name for their future child, such concrete associations with specific celebrities and ensuing abstract associations with symbolic features such as modernity, can clearly influence their decision. In the second study presented in this paper, we aim to measure the strength of association of certain first names with specific referents from the Anglo-American sphere of influence. To this end, a free response association experiment was set up (compare Grondelaers and Speelman 2015).

\subsection{ASSOCIATION EXPERIMENT: DESIGN AND PROCEDURE}

Through a Google Form survey drafted in Dutch, participants were asked to fill in the first three (famous) people that leapt to mind when reading a specific first name. We explicitly added that we were looking for spontaneous thoughts, not answers resulting from Internet searches. On the final page of the survey, respondents were asked to list their age and gender. In total, the survey includes twenty-four questions of the type "Which famous person do you think of when hearing the name...". Nine of these names serve as fillers to obscure the purpose of our survey. They include Dutch (Sofie, Niels), French (Fleur, Louis) and Italian (Matteo) names that do not have clear famous referents.

The fifteen remaining names are the actual stimuli of the experiment: for these names, it was easily possible to come up with at least one celebrity from AngloAmerican pop culture (Table 3). Ten of these names (Emma, Keano, Lana, Mila, Olivia, Liv, Simon, Sam, Liam \& Amy) are selected from our K\&G database, only two of which are etymologically English (Liam and Amy). Five names were added that do not appear in the top 75 names in Flanders in the past ten years but that do have clear Anglo-American celebrity referents (Naomi, Justin, Demi, Kim, Rowan). According to the database from Meertens Instituut, Kim is the only one of these five names with etymologically English roots.

\begin{tabular}{|l|l|l|}
\hline First name & Possible celebrity surnames & Main 'celebrity' activity \\
\hline Emma & Watson & actress (Harry Potter) \\
& Stone & actress \\
& Roberts & actress \\
& Thompson & actress \\
\hline Keano & Reeves & actor (The Matrix) \\
\hline Lana & del Rey & singer, model \\
\hline Mila & Kunis & actress (That Seventies Show) \\
\hline Olivia & Newton-John & singer and actress (Grease) \\
& Wilde & actress (House M.D.) \\
\hline Liv & Tyler & actress, model \\
\hline Simon & Cowell & TV talent judge \\
\hline Sam & Sparro & singer \\
& Smith & singer \\
\hline
\end{tabular}




\begin{tabular}{|l|l|l|}
\hline Liam & $\begin{array}{l}\text { Neeson } \\
\text { Hemsworth }\end{array}$ & $\begin{array}{l}\text { actor } \\
\text { actor (Neighbours) }\end{array}$ \\
\hline Amy & Winehouse & Singer \\
\hline Naomi & Campbell & Model \\
\hline Justin & $\begin{array}{l}\text { Bieber } \\
\text { Timberlake }\end{array}$ & $\begin{array}{l}\text { singer } \\
\text { singer (NSYNC), actor }\end{array}$ \\
\hline Demi & $\begin{array}{l}\text { Moore } \\
\text { Lovato }\end{array}$ & $\begin{array}{l}\text { actress } \\
\text { singer, actress (Glee) }\end{array}$ \\
\hline Kim & Kardashian & TV personality \\
\hline Rowan & Atkinson & actor (Mr. Bean, Blackadder $)$ \\
\hline
\end{tabular}

Table 3. Stimuli for the association experiment

The survey was completed by 33 participants ( 21 women, 12 men). We selected participants between 25 and 38 years old (with a mean age of 28), which is the age when Flemish women typically have their first baby. Given the limited number of completed surveys, we have to be careful not to overstate our results. As a safe-guard, we work with a weighting factor and a strict cut-off when measuring the strength of the referential associations.

\subsection{RESULTS}

All associations listed for the stimuli are provided in the Appendix. In processing the results, a weighting factor was used. Names that are listed as the first of three associations receive triple weight; names listed secondly receive double weight; names listed as the final of three associations are counted only once. Aggregating over the 33 participants, association with a given celebrity can reach a maximal score of 99 (i.e. when that celebrity is listed as the first association by all 33 participants). As an example, consider the association between the first name Justin and the American pop singer Justin Bieber. Ten participants listed Bieber as first association, thirteen listed Bieber as second association, none listed him as third association. This provides Justin Bieber with an association score of $((10 * 3)+(13 * 2)+(0 * 1)) / 100=$ 0.57 for the first name Justin. All noteworthy association scores are listed in Table 4. To compensate for the low number of respondents to our survey, we adopt a strict threshold and only include associations of 0.70 or higher.

\begin{tabular}{llr}
\hline first name & referent & association score \\
\hline \hline Amy & Amy Winehouse & 0.94 \\
Demi & Demi Moore & 0.91 \\
Naomi & Naomi Campbell & 0.86 \\
Lana & Lana Del Rey & 0.82 \\
Justin & Justin Timberlake & 0.81
\end{tabular}




\begin{tabular}{lll} 
Keano & Keanu Reeves & 0.78 \\
Emma & Emma Watson & 0.77 \\
Liv & Liv Tyler & 0.70 \\
\hline
\end{tabular}

Table 4. Top association scores

None of the nine fillers yielded notable association scores. For the stimuli, strong associations with one specific celebrity are noted for eight out of fifteen stimuli. Given the strong link between the first names and these referents (Table 4), it is quite possible that the first names have acquired associative meaning through these referents. The name is metonymically linked to the referent, which is in itself metonymically tied to Anglo-American pop culture. As such, symbolic values of Anglo-American pop culture are eventually attached as stereotypes to the first names.

Claiming a direct link between parents' choice of name and our association experiment is of course a dangerous endeavor: complementary attitudinal research is needed. One way to provide some preliminary insight into the connection between referential association and naming can however also be acquired by linking the results back to the $K \& G$ naming database with attention for the cultural bearers of the name. Below, we provide a highly exploratory example of such a socio-culturally embedded analysis for Amy, the name with the highest association score, Amy.

\subsection{FROM SURVEY TO DATABASE: AMY}

Of our thirty-three respondents, thirty-one list Amy Winehouse as only association with the first name Amy. This very clear connection between name and referent raises the question whether the diachronic naming patterns for Amy in Flanders can be linked to the professional career of Amy Winehouse. The English jazz and soul singer released her debut album in 2003. It is however her second album, Back into Black (released in the UK in October 2006), that made her world-famous. Her success peaked in 2007. On 23 July 2011, Amy Winehouse died of alcohol poisoning, which caused a short revival of the album Back into Black. 


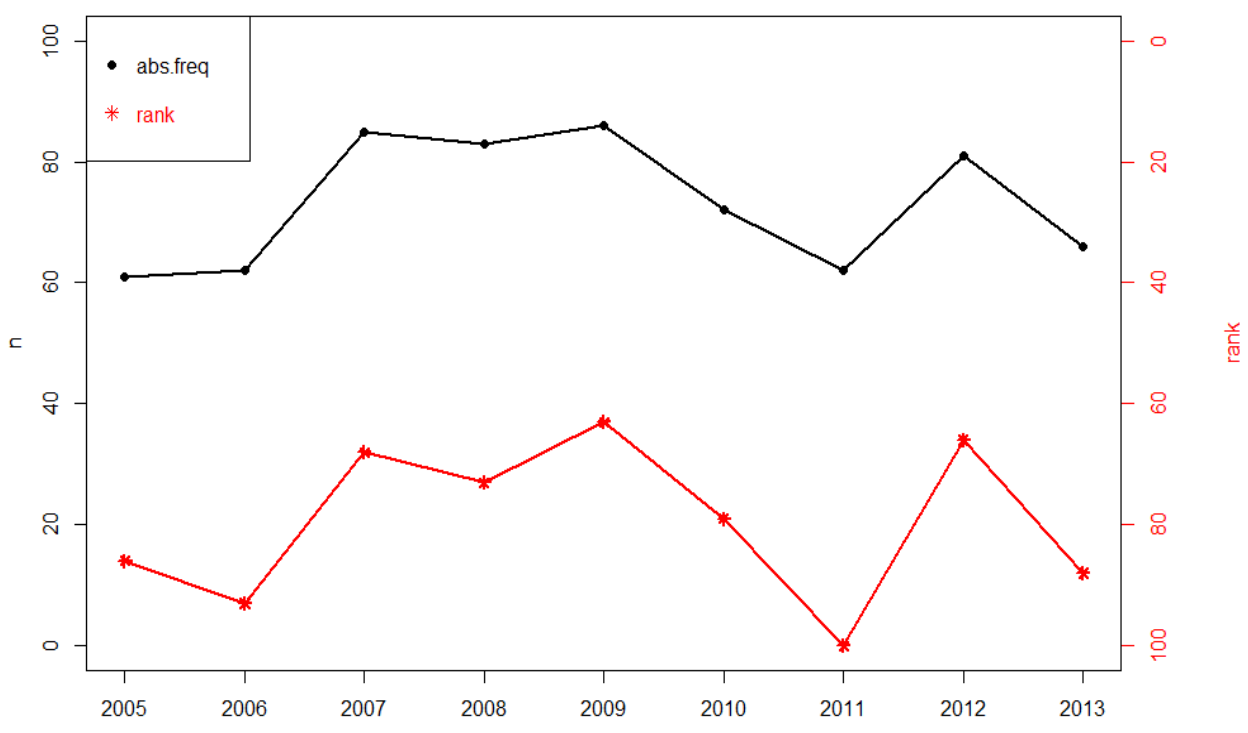

Figure 4. Diachronic patterns for Amy in the K\&G database

Figure 4 summarizes the success of the first name Amy in Flanders. The red line on the plot provides information on the rank of the name, the black line provides the evolution in absolute frequencies. Although the patterns are mild, it is still striking to see how the life and career of Amy Winehouse seem to coincide with the diachronic evolution in naming found in Figure 4. Amy's most popular album was released at the end of 2006, which is reflected by a surge in popularity for Amy in 2007. As her career comes to a stand-still, the name loses ground to reach a minimum in 2011 . Her death in July 2011 seems to instigate a short revival of the name in 2012. Of course we have to be aware of the distinction between correlation and causation, and more research is needed to dig into different links between naming and referential associations. At the very least, though, we find convincing indications that further attention for the impact of referential associations on the Englishization of naming patterns is warranted.

\section{CONCLUSION}

This paper aims to contribute to the ongoing shift from a structuralist to a sociopragmatic perspective in anglicism research and to the social turn in onomastics, by 
studying Englishization effects on naming practices in Flanders. Two perspectives are combined, accounting for the two ways in which names acquire associative meaning: through their phonological form and through the specific people bearing the name (Van Langendonck 2002).

Some interesting preliminary results were found, although we also noted shortcomings to the methods we relied on. Both are summarized below, where necessary complemented with suggestions for future research. As a first step, we drafted a dataframe containing all top 75 boy names and all top 75 girl names for each year in the period 2005-2014, based on K\&G's online naming database. The first name database from Meertens Instituut was used to provide etymological information for the 114 different boy names and 127 different girl names. This information was used to pattern the diachronic evolution in the preference for English names. Similar to the country-of-origin effect in marketing, parents might select English(-sounding) names for their children because these are metonymically linked to the speakers of English, and through these speakers, to symbolic values of Englishization and globalization such as fun, modernity and internationalism. Despite the strong position of English in Flanders (see e.g. Zenner et al. 2013b), no indications of ongoing Englishization were found. This might indicate that phonological associations do not play a strong role in naming patterns in Flanders. We however have to be careful with such assertions, as our method is not without fault.

First, our diachronic analysis is conducted in a 10-year window, which might be too short to see clear patterns. Nevertheless, this window is located precisely where we would expect to see a high amount of English names (2005-2014). No such peak is found: in 2014 only 10 of 150 ranked names are English. Again, caution is needed. As was explained above, relying on etymological information might not be the best way to measure phonological associations triggered by first names. On the one hand, names that are etymologically English might not be considered as such (e.g. Cedric). Attitudinal research could be a way to assess which phonological associations are made by young parents. On the other hand, names that are etymologically not English might nevertheless trigger associations with Anglo-American culture through the people bearing that name (e.g. Slavic Lana triggering associations with pop culture through Lana Del Rey).

Ideally, we would verify the strength of associations with Anglo-American celebrities for every name in our database through a large-scale experimental survey. At this point, we were restricted to a preliminary association study, where 33 participants (mean age 28) were asked to list the three first celebrities that leapt to mind when confronted with a specific first name. For eight of fifteen stimuli, very clear referential associations were noted. It is not unlikely that these referents play a role in name-giving patterns. Not only do these names evoke characteristics of Anglo-American cultural models, they also index more symbolic features linked to the growing internationalization of the media and to what Bayard et al. (2001: 44) 
call the "unceasing global media onslaught". Again, future attitudinal research is needed, but a preliminary analysis of the diachronic evolution of Amy showed promising results. Peaks in the preference for Amy can be linked to specific points of Amy's career. Such diachronic analysis need to be repeated for different names where strong referential association can be noted, and qualitative research is needed that verifies to what extent specific referents are taken into account in naming. A remaining issue is the question of innovation and propagation of first names. Sociocultural influence of Anglo-American pop culture in general and of specific referents in particular will most probably play a bigger part in innovation than in propagation. For example, the first parents that name their child Mila might be influenced by the American actress Mila Kunis. As the name starts propagating, a point will be reached where the name is so entrenched in the Flemish naming landscape that the link with Mila Kunis is smoothed out. People can then copy the name without explicit mental reference to the American actress. How frequent a name has to occur before the link with a referent loses importance and how the path from innovation to propagation can be traced are of a complexity that cannot be dealt with through the analysis presented here.

Nevertheless, some clear conclusions can be drawn. First, an etymological analysis of English names in the period 2005-2014 shows no clear increase nor a sound position of English-origin names in Flanders. Second, an exploratory experimental task shows clear referential associations between first names and bearers of that name from Anglo-American pop culture. More generally, our analysis reveals how the focus on etymological background of first names deserves to be relaxed, making room for attention for referential associations. Finally, on a more theoretical level, the attested results support the value of the socio-pragmatic turn of both anglicism research and onomastics.

\section{ACKNOWLEDGMENTS}

The first author is supported by a personal grant of FWO (the National Science Foundation of Flanders). Additionally, we would like to thank Maartje Everaert, Yoni Froyen and Katrien Hertogs. This study would not have been possible without the pilot study resulting from the dedicated hard work performed by these three MA students.

\section{REFERENCES}

Andersen, Gisle (2014). Pragmatic borrowing. Journal of Pragmatics 67: 17-33. Anderson, John M. (2003). On the structure of names. Folia Linguistica 37. 3/4: 347398. 
Bayard, Donn, Ann Weatherall, Cynthia Gallois and Jeffery Pittam (2001). Pax Americana? Accent attitudinal evaluations in New Zealand, Australia and America. Journal of Sociolinguistics 5: 22-49.

Beech, George T., Monique Bourin and Pascal Chareille, eds. (2002). Personal Names Studies of Medieval Europe. Social Identity and Familial Structures. Michigan: Kalamazoo Western Michigan University.

Bruck, Gabriela vom and Barbara Bodenhorn (2006). The Anthropology of Names and Naming. Cambridge: Cambridge University Press.

Chao, Paul; Gerard Würher and Thomas Werani (2005). Celebrity and foreign brand name as moderators of country-of-origin effects. International journal of advertising 24.2: 173-192.

Clifton, Jonathan (2013). What's in a name? Names, national identity, assimilation, and the new racist discourse of Marine Le Pen. Pragmatics 23.3: 403-420.

De Stefani, Elwis (2016). Names and discourse. To appear in: Carole Hough, ed., The Oxford Handbook of Names and Naming. Oxford: Oxford University Press.

De Stefani, Elwis and Nicolas Pepin (2006). Une approche interactionniste de l'étude de noms propres. Les surnoms de famille. Onoma 41: 131-162.

Duguet, Emmanuel ; Noam Leandri ; Yannick L'Horty and Pascale Petit (2010). Are young French jobseekers of ethnic immigrant origin discriminated against? A controlled experiment in the Paris area. Annals of Economics and Statistics/ Annales d' Économie et de Statistique 99/100: 187-215.

Finch, Janet (2008). Naming names: Kinship, individuality and personal names. Sociology 42.4: 709-725.

FOD Economie (2014). Bevolking - Cijfers bevolking 2010-2015. $<$ http://statbel.fgov.be/nl/modules/publications/statistiques/bevolking/bevolking _ -_cijfers_bevolking_2010_-_2012.jsp> (Accessed November 6 2015).

Frege, Gottlob (1892). Über Sinn und Bedeutung. Zeitschrift für Philosophie und philosophische Kritik NF 100.25 ff.

Friedrich, Patricia (2002). English in advertising and brand naming: sociolinguistic considerations and the case of Brazil. English Today 71.18: 21-28.

Furiassi, Cristiano and Henrik Gottlieb (2015). Pseudo-English. Studies on False Anglicisms in Europe. Berlin/NY: Mouton de Gruyter.

Gerritsen, Marinel; Catherine Nickerson; Andreu Van Hooft; Frank van Meurs; Ulrike Nederstigt; Marianne Starren and Rogier Crijns (2007). English in product advertisements in Belgium, France, Germany, the Netherlands and Spain. World Englishes 26.3: 291-315.

Gilquin, Gaëtanelle (2015). At the interface of contact linguistics and second language acquisition research: New Englishes and Learner Englishes compared. English World-Wide: A journal of varieties of English 36.1: 91-124.

Görlach, Manfred (2001). A dictionary of European anglicisms: A usage dictionary of anglicisms in sixteen European languages. Oxford: Oxford University Press. 
Gottlieb, Henrik (2014). True figures, false love, the return of William and the naming of storms: Pragmatic English borrowing in Denmark. Paper presented at the 12th ESSE conference. Slovakia: Kosice.

Grondelaers, Stefan and Dirk Speelman (2015). A quantitative analysis of qualitative free response data. In Jocelyne Daems, Eline Zenner, Kris Heylen, Dirk Speelman and Hubert Cuyckens, eds., Change of Paradigms: New Paradoxes, 361-384. Berlin/NY: Mouton de Gruyter.

Hanks, Patrick, Kate Hardcastle and Flavia Hodges (2006). Oxford Dictionary of First Names ( $2^{\text {nd }}$ edition). Oxford: Oxford University Press.

Hendrikx, Berna, Frank van Meurs and Els van der Meij (2015). Does a foreign accent sell? The effect of foreign accents in radio commercials for congruent and non-congruent products. Multilingua 34.1: 119-130.

Hoffer, Bates L. (1996). Borrowing/Lehnvorgänge/Emprunt linguistique. In Hans Goebl, Peter H. Nelde, Zdenek Stary and Wolfgang Wölck, eds., Kontaktlinguistik: ein internationales Handbuch zeitgenössischer Forschung/ Contact linguistics: an international handbook of contemporary research/ Linguistique de contact: manuel international des recherches contemporaines (541-548). Berlin/NY: De Gruyter.

Hornikx, Jos and Frank Meurs (2015). Foreign language display in advertising from a psycholinguistic and sociolinguistic perspective: A review and research agenda. In J. M. Alcántara-Pilar, S. del Barrio-García, E. Crespo-Almedros and L. Porcu, eds., Analyzing the cultural diversity of consumers in the global marketplace (pp. 299-319). Hershey: IGI Global.

Hornikx Jos, Frank van Meurs and Robert-Jan Hof (2013). The effectiveness of foreign-language display in advertising for congruent versus incongruent products. Journal of International Consumer Marketing 25.3, 152-165.

Hornikx, van Meurs and Starren (2007). An empirical study of readers' associations with multilingual advertising: the case of French, German and Spanish in Dutch advertising. Journal of Multilingual and Multicultural Development, 28.3.

Hough, Carole, ed. (2016). The Oxford Handbook of Names and Naming. Oxford: Oxford University Press.

Kelly-Holmes, Helen (2000) Bier, parfum, kaas: Language fetish in European advertising. European Journal of Cultural Studies 3.1: 67-82.

Kelly-Holmes, Helen (2005). Advertising as Multilingual Communication. New York: Palgrave MacMillan.

Koß, Gerhard (2002). Namenforschung. Eine Einführung in die Onomastik. Tübingen: Max Niemeyer.

Kripke, Saul (1980). Naming and necessity. Cambridge: Harvard University Press.

Kristiansen, Gitte (2008). Style-shifting and shifting styles: A socio-cognitive approach to lectal variation. In Gitte Kristiansen and René Dirven, eds., Cognitive Sociolinguistics. Language Variation, Cultural Models, Social Systems (pp. 4590). Berlin/New York: Mouton de Gruyter. 
Leclerc, France, Bernd H. Schmitt, and Laurette Dubé (1994). Foreign branding and its effects on product perceptions and attitudes. Journal of marketing research 31.2: $263-270$.

Lee, Sangwon and Daniel W. Baack (2014). The meaning or sound? The effects of brand name fluency on brand recall and willingness to buy. Journal of promotion management 20.5: 521-539.

Levit, Steven and Stephen Dubner (2005). Freakonomics. A Rogue Economist Explores the Hidden Side of Everything. NY: William Morrow.

Lukas, Rainer Friedrich Wilhelm (1981). Die Vornamengebung in Schwalmstadt Ziegenhain und Gießen von 1945 bis 1975. Frankfurt am Main.

Martin, Elizabeth (2006). Marketing Identities through Language: English and Global Imagery in French Advertising. New York: Palgrave Macmillan.

Mauranen, Anna and Elina Ranta (2009). English as a Lingua Franca: Studies and Findings. Newcastle upon Tyne: Cambridge Scholars Press.

Meurs, Frank van; Jos Hornikx and Gerben Bossenbroek (2014). English loanwords and their counterparts in Dutch job advertisements: An experimental study in association overlap. In Eline Zenner and Gitte Kristiansen, eds., New perspectives on lexical borrowing: Onomasiological, methodological and phraseological innovations (pp.171-190). Berlin: Mouton de Gruyter.

Onysko, Alexander and Esme Winter-Froemel (2011). Necessary Loans - Luxury Loans? Exploring the Pragmatic Dimension of Borrowing. Journal of Pragmatics 43.6: $1550-1567$.

Palsson, Gisli (2014). Personal names, embodiment, differentiation exclusion, and belonging. Science, Technology, \& Human Values. 39.4: 618-630.

Peterson, Elizabeth and Johanna Vaattovaara (2014). Kiitos and pliis: The relationship of native and borrowed politeness markers in Finnish. Journal of Politeness Research 10.2: 247-269.

Piller, Ingrid (2001). Identity Constructions in Multilingual Advertising. Language in Society 30.2, 153-186.

Pina-Cabral, Joao de (2010). The truth about personal names. Journal of the Royal Anthropological Institute 16.2: 297-312.

Poplack, Shana; David Sankoff and Chris Miller (1988). The social correlates and linguistic processes of lexical borrowing and assimilation. Linguistics 26: 47-104.

Posthumus, Jan (1986). A description of a corpus of anglicisms. Groningen: Anglicistisch Instituut.

Samiee, S. (1994). Customer evaluation of products in a global market. Journal of International Business Studies 25: 579-604.

Schürer, Kevin (2004). Surnames and the Search for Regions. Local Population Studies 72: 50-76.

Stefanowitsch, Anatol (2002). Nice to miet you: bilingual puns and the status of English in Germany. Intercultural Communication Studies 11.4: 67-84. 
Tyberg, Son (2014). 10.000 voornamen met hun herkomst en betekenis. Aartselaar: Deltas.

Usunier, J. C. and G. Cestre (2007). Product ethnicity: Revisiting the match between products and countries. Journal of International Marketing 15: 32-72.

Van de Velde, Freek and Eline Zenner (2010). Pimp my Lexis: het nut van corpusonderzoek in normatief taaladvies. In Els Hendrickx, Karl Hendrickx, Willy Martin, Hans Smessaert, William Van Belle and Joop Van der Horst, eds., Liever meer of juist minder? Over normen en variatie in taal (pp. 51-68). Gent: Academia Press.

Van Langendonck, Willy (2002). Theory and Typology of Proper Names. Berlin/NY: Mouton de Gruyter.

Wolf, Hans-Georg and Frank Polzenhagen (2009). World Englishes. A Cognitive Sociolinguistic Approach. Berlin/New York: Mouton de Gruyter.

Yang, Wenliang (1990). Anglizismen im Deutschen. Tübingen: Max Niemeyer Verlag.

Zenner, Eline, Dirk Speelman and Dirk Geeraerts (2012). Cognitive Sociolinguistics Meets Loanword Research: Measuring Variation in the Success of Anglicisms in Dutch. Cognitive Linguistics 23.4: 749-92.

Zenner, Eline, Dirk Speelman and Dirk Geeraerts (2013a). What makes a catchphrase catchy? Possible determinants in the borrowability of English catchphrases in Dutch. In Eline Zenner and Gitte Kristiansen, eds., New Perspectives on Lexical Borrowing (pp. 41-64). Berlin/New York: Mouton de Gruyter.

Zenner, Eline, Dirk Speelman and Dirk Geeraerts (2013b). Macro and micro perspectives on the distribution of English in Dutch. A quantitative usage-based analysis of job ads. Linguistics 51.5: 1019-1064.

\section{APPENDIX: SURVEY RESULTS}

\begin{tabular}{llrrrrr}
\hline stimulus & Connotations & first occ & second occ & third occ & total mentions & weighted (...99) \\
\hline \hline Emma & Emma Watson & $\mathbf{2 4}$ & $\mathbf{2}$ & $\mathbf{0}$ & $\mathbf{2 6}$ & $\mathbf{0 . 7 7}$ \\
Emma & Baby Spice & 3 & 1 & 1 & 5 & 0.12 \\
Emma & Emma Thompson & 2 & 0 & 0 & 2 & 0.06 \\
Emma & Emma uit Thuis & 2 & 1 & 0 & 3 & 0.08 \\
Emma & Emma (Jane Austen) & 1 & 0 & 1 & 2 & 0.04 \\
Emma & Kindje uit Friends & 1 & 0 & 1 & 2 & 0.04 \\
Emma & Emma (Charlotte Brönte) & 0 & 0 & 1 & 1 & 0.01 \\
Emma & Emma Bovary & 0 & 1 & 0 & 1 & 0.02 \\
Emma & Emma Rappé & 0 & 1 & 0 & 1 & 0.02
\end{tabular}




\begin{tabular}{|c|c|c|c|c|c|c|}
\hline Emma & Emma Stone & 0 & 3 & 0 & 3 & 0.06 \\
\hline Emma & personage 'One Day' & 0 & 1 & 0 & 1 & 0.02 \\
\hline Emma & Uma Thurman & 0 & 1 & 0 & 1 & 0.02 \\
\hline Emma & [empty] & 0 & 22 & 29 & & \\
\hline Justin & Justin Timberlake & 22 & 7 & $\mathbf{0}$ & 29 & 0.81 \\
\hline Justin & Justin Bieber & 10 & 13 & 0 & 23 & 0.57 \\
\hline Justin & Justine Henin & 1 & 1 & 5 & 7 & 0.10 \\
\hline Justin & Justin Gatlin & 0 & 1 & 0 & 1 & 0.02 \\
\hline Justin & [empty] & 0 & 11 & 28 & & \\
\hline Keano & Keanu Reeves & 25 & 1 & $\mathbf{0}$ & 26 & 0.78 \\
\hline Keano & Keano Gooris & 4 & 2 & 0 & 6 & 0.16 \\
\hline Keano & [empty] & 4 & 30 & 33 & & \\
\hline Sam & Sam Gooris & 16 & 1 & 0 & 17 & 0.51 \\
\hline Sam & Sam De Bruyn & 4 & 0 & 0 & 4 & 0.12 \\
\hline Sam & Sam Sparro & 3 & 1 & 0 & 4 & 0.11 \\
\hline Sam & Sam Deltour & 1 & 0 & 0 & 1 & 0.03 \\
\hline Sam & Sam Smith & 1 & 0 & 0 & 1 & 0.03 \\
\hline Sam & Sam van Samang & 1 & 1 & 0 & 2 & 0.05 \\
\hline Sam & Sam Warburton & 1 & 0 & 0 & 1 & 0.03 \\
\hline Sam & Samson & 1 & 4 & 0 & 5 & 0.11 \\
\hline Sam & Samuel L. Jackson & 1 & 0 & 2 & 3 & 0.05 \\
\hline Sam & Uncle Sam & 1 & 0 & 1 & 2 & 0.04 \\
\hline Sam & Sam Allardyce & 0 & 0 & 1 & 1 & 0.01 \\
\hline Sam & Sam De Graeve & 0 & 1 & 0 & 1 & 0.02 \\
\hline Sam & Sam Stosur & 0 & 1 & 0 & 1 & 0.02 \\
\hline Sam & Stan Van Samang & 0 & 0 & 1 & 1 & 0.01 \\
\hline Sam & [empty] & 3 & 24 & 28 & 55 & \\
\hline Lana & Lana Del Rey & 27 & $\mathbf{0}$ & $\mathbf{0}$ & 27 & 0.82 \\
\hline Lana & Alanis Morissette & 1 & 0 & 0 & 1 & 0.03 \\
\hline Lana & Lana Lang (Smallville) & 1 & 1 & 0 & 2 & 0.05 \\
\hline Lana & Lara Croft & 0 & 1 & 0 & 1 & 0.02 \\
\hline Lana & Personage uit Dokter Zhivago & 0 & 1 & 0 & 1 & 0.02 \\
\hline Lana & [empty] & 4 & 30 & 33 & & \\
\hline Liv & Liv Tyler & 23 & $\mathbf{0}$ & $\mathbf{0}$ & 23 & 0.70 \\
\hline Liv & Leo Tolstoj & 1 & 0 & 0 & 1 & 0.03 \\
\hline
\end{tabular}




\begin{tabular}{|c|c|c|c|c|c|c|}
\hline Liv & [empty] & 9 & 33 & 33 & & \\
\hline Kim & Kim Clijsters & 12 & 6 & 0 & 18 & 0.48 \\
\hline Kim & Kim Kardashian & 11 & 5 & 1 & 17 & 0.44 \\
\hline Kim & Kim Gevaert & 4 & 4 & 1 & 9 & 0.21 \\
\hline Kim & Kim Kay & 2 & 1 & 1 & 4 & 0.09 \\
\hline Kim & Kim Basinger & 1 & 0 & 0 & 1 & 0.03 \\
\hline Kim & Kim De Gelder & 1 & 0 & 2 & 3 & 0.05 \\
\hline Kim & Kim Holland & 0 & 1 & 0 & 1 & 0.02 \\
\hline Kim & Kim Jong-II & 0 & 0 & 1 & 1 & 0.01 \\
\hline Kim & Kim Wilde & 0 & 1 & 0 & 1 & 0.02 \\
\hline Kim & Lil' Kim & 0 & 1 & 0 & 1 & 0.02 \\
\hline Kim & [empty] & 2 & 14 & 27 & & \\
\hline Liam & Liam Neeson & 11 & 4 & 0 & 15 & 0.41 \\
\hline Liam & Liam Gallagher & 10 & 3 & 0 & 13 & 0.36 \\
\hline Liam & Liam Hemsworth & 1 & 0 & 0 & 1 & 0.03 \\
\hline Liam & Liam Messam & 1 & 0 & 0 & 1 & 0.03 \\
\hline Liam & Liam Spencer & 1 & 0 & 0 & 1 & 0.03 \\
\hline Liam & [empty] & 9 & 26 & 33 & & \\
\hline Simon & Simon \& Garfunkel & 12 & 1 & 0 & 13 & 0.38 \\
\hline Simon & Simon Cowell & 6 & 1 & 0 & 7 & 0.20 \\
\hline Simon & Simon uit "Sara" & 2 & 0 & 0 & 2 & 0.06 \\
\hline Simon & Simon Carmiggelt & 1 & 0 & 0 & 1 & 0.03 \\
\hline Simon & Simon Clarke & 1 & 0 & 0 & 1 & 0.03 \\
\hline Simon & Simon Dust & 1 & 0 & 0 & 1 & 0.03 \\
\hline Simon & Simon Gronowski & 1 & 0 & 0 & 1 & 0.03 \\
\hline Simon & Simon Jackson & 1 & 0 & 0 & 1 & 0.03 \\
\hline Simon & Simon MC (Eurosong) & 1 & 0 & 0 & 1 & 0.03 \\
\hline Simon & Simon Stevin & 1 & 3 & 0 & 4 & 0.09 \\
\hline Simon & Simonneke (Thuis) & 1 & 0 & 0 & 1 & 0.03 \\
\hline Simon & Simon Mignolet & 0 & 1 & 1 & 2 & 0.03 \\
\hline Simon & Simon Van Cyrene & 0 & 0 & 1 & 1 & 0.01 \\
\hline Simon & [empty] & 5 & 27 & 31 & & \\
\hline Roan & Rowan Atkinson & 8 & 0 & 0 & 8 & 0.24 \\
\hline Roan & Ronan Keating & 3 & 0 & 0 & 3 & 0.09 \\
\hline Roan & Roan Charles & 1 & 0 & 0 & 1 & 0.03 \\
\hline
\end{tabular}




\begin{tabular}{|c|c|c|c|c|c|c|}
\hline Roan & Rowwen Hèze & 1 & 0 & 0 & 1 & 0.03 \\
\hline Roan & [empty] & 20 & 33 & 33 & & \\
\hline Demi & Demi Moore & 30 & $\mathbf{0}$ & $\mathbf{0}$ & 30 & 0.91 \\
\hline Demi & Demi uit Idols & 1 & 0 & 0 & 1 & 0.03 \\
\hline Demi & Demi Lovato & 0 & 2 & 0 & 2 & 0.04 \\
\hline Demi & [empty] & 2 & 31 & 33 & & \\
\hline Mila & Mila Kunis & 20 & 0 & 0 & 20 & 0.61 \\
\hline Mila & Mila Jovovich & 2 & 0 & 0 & 2 & 0.06 \\
\hline Mila & Miley Cyrus & 2 & 0 & 0 & 2 & 0.06 \\
\hline Mila & Milow & 0 & 1 & 0 & 1 & 0.02 \\
\hline Mila & [empty] & 9 & 32 & 33 & & \\
\hline Amy & Amy Winehouse & 31 & $\mathbf{0}$ & $\mathbf{0}$ & 31 & 0.94 \\
\hline Amy & Amy McDonald & 1 & 1 & 0 & 2 & 0.05 \\
\hline Amy & Amy Butler & 0 & 1 & 0 & 1 & 0.02 \\
\hline Amy & [empty] & 1 & 31 & 33 & & \\
\hline Naomi & Naomi Campbell & 27 & 2 & $\mathbf{0}$ & 29 & 0.86 \\
\hline Naomi & Naomi Watts & 5 & 5 & 0 & 10 & 0.25 \\
\hline Naomi & Naomi Klein & 0 & 1 & 0 & 1 & 0.02 \\
\hline Naomi & Naomi Wolf & 0 & 1 & 0 & 1 & 0.02 \\
\hline Naomi & [empty] & 1 & 24 & 33 & & \\
\hline Olivia & Olivia Newton-John & 8 & 0 & 0 & 8 & 0.24 \\
\hline Olivia & Olivia Wilde & 8 & 0 & 0 & 8 & 0.24 \\
\hline Olivia & Olivia Pope & 2 & 0 & 0 & 2 & 0.06 \\
\hline Olivia & Olivia uit Popeye & 2 & 0 & 0 & 2 & 0.06 \\
\hline Olivia & Olivia Borlée & 1 & 0 & 0 & 1 & 0.03 \\
\hline Olivia & Olivia Twist & 1 & 0 & 0 & 1 & 0.03 \\
\hline Olivia & Olivia uit Thuis & 0 & 1 & 0 & 1 & 0.02 \\
\hline Olivia & [empty] & 11 & 32 & 33 & & \\
\hline
\end{tabular}

